\title{
Copper King Mining Company: A Case Study In Using Loans And Equity To Finance A Start-Up
}

Richard Parsons, Ph.D., Texas A\&M University - Texarkana, USA

\begin{abstract}
The proposed Copper King mine in south central Utah was expected to produce millions of dollars in copper, gold and silver. A nearby struggling town and thousands of speculators and large banks seized upon this promise. They all were willing to invest in developing the mine. Copper King tried a wide variety of financing approaches, one at a time, over a several year period during which a significant amount of funds were raised. The financing options employed allow a study of the technical financing requirements of each of the options (hard money loans, waterfall loans, private equity and public equity). Copper King Mining Company is a lesson in the difficulties of financing a start-up. Important theoretical concepts include the problem of banks dealing with asymmetric information and moral hazard, along with the tools they use to mitigate that risk. Asset valuation and the price of risk are also important lessons in this case.
\end{abstract}

This case is most appropriate for classes in corporate finance, money and banking, investing and entrepreneurship.

Keywords: Financing a Start-Up; Raising Funds; Private and Public Equity; Moral Hazard and Asymmetric Information

\section{MARK DOTSON AND THE CREATION OF AN ASSET}

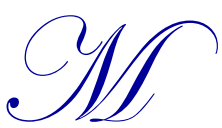

ark Dotson had mining in his blood. He was born on a gold claim; his father was a prospector, and he spent his life in and around the mines of the historically rich Milford mineral belt. He knew all the local miners and worked as one himself.

The Milford mineral belt is a remote area located in central Utah. In the 1950s, rising mineral prices and new technologies making extraction easier created renewed interest in the Milford mineral belt. As a result of the local mining history dating back to the 1800 s, ownership of the mineral claims, land leases, and mining rights were small and fragmented. Many claims were held in bankruptcy and by "old timers." In the 1960s and 1970s, several large companies tried to buy the various rights so that a consolidated operation could be put in place with more efficient operation (Palladon Ventures, 2003). Unfortunately, the locals and "old timers" did not trust the large corporations, and those efforts failed.

Mark Dotson, however, succeeded where the large corporations failed. He spent over 15 years meticulously assembling ownership and rights to over 27 fragmented claims (Oberbeck, 2009). He picked up many of the claims in bankruptcy for little money and negotiated royalty agreements with the locals who trusted him. Eventually he assembled almost 60,000 acres of mining claims with a focus on copper, gold, and silver; he called the whole deal the Western Utah Copper Company (WUCC). Perhaps the most prized asset within the WUCC was the rights to the inactive Hidden Treasure mine owned by the Nevada Star Corporation.

\section{The Challenge}

Mark Dotson faced the task of raising significant funds to develop Western Utah Copper. Development of a processing mill required between $\$ 60$ and $\$ 100$ million, and additional funds were needed to pay for leases, 
royalties, and equipment. Mark Dotson couldn't raise the money locally, as the impoverished area was barely surviving. Mark was confident in his knowledge of mining and wanted to retain complete control of the operation and decision making; however, he did not have experience in finance and did not have contacts with money.

In most cases, those who lend money require something in return in order to compensate for the risks associated with adverse selection and moral hazard. Lenders usually require collateral along with monitoring and enforcement of restrictive covenants - these requirements conflicted with Mark's objectives. During the course of his development of the mine, he had to find a way to balance his objectives with the needs of his investors. Mark Dotson quickly learned the benefits and constraints associated with each of the financing options considered. Copper King Mining Company provided a lesson on the difficulties of financing a start-up. As such, Mark Dotson learned some important concepts about how banks and investors deal with asymmetric information and the tools they use to mitigate their risk.

\section{The Mining Industry}

The metal ore mining industry is based on a large global market. Most modern-day mining companies are large, international corporations. The need for significant capital expenditures and the risks associated with reliance on volatile world commodity prices have led to the development of larger and larger companies through acquisitions and mergers. Mining companies have very specialized heavy equipment, such as specialty large trucks and bulldozers, which require significant capital spending. They also need to build and operate a mill near the mining site so that they only pay to ship the ore and not the large quantities of base rock that are discarded. For reference, the Western Utah Copper Company mine was expected to produce 36 pounds of copper out of one ton of rock.

The Western Utah Copper Company mine was a surface mine. The top layers of dirt and rock were removed until one reached the ore. Then the base rock, including the ore deposits, were broken up and transported to the mill where the ore was separated. An example of the world's largest copper mine is available for viewing on youtube.com, in a video called Kennecott's Bingham Copper Mine (9:50). Kennecott is an open pit mine similar to the Western Utah Copper mine. More information about copper milling and smelting is available in the YouTube video Inco Copper Cliff Smelter Complex Video, Sudbury Ontario (7:31).

\section{What is the Asset Worth?}

There was no doubt that the claims assembled by Dotson represented a valuable asset. Millions of dollars in copper, gold, and silver were expected to be extracted and save a struggling town in south central Utah. Experts and banks all recognized the value. A geologist told a company officer that the mine had the potential to be ten times the size of Kennecott's Bingham Canyon Mine, which has produced more copper than any other mine in history (Romboy, 2011b). Preliminary estimates forecasted an EBITDA of $\$ 120$ million a year once a mill was in operation. However, significant investment was required. The cost of building the mill was between $\$ 60$ and $\$ 100$ million. Additional funds of approximately $\$ 10$ million were needed to cover startup costs. In calculating a value for the mine, investors assumed a depreciation life of 10 years and a standard corporate tax rate of $35 \%$.

\section{DEVELOPMENT OF THE ASSET}

Mark Dotson forged a financial partnership with an experienced mining venture capital fund, Palladon Ventures. This agreement, announced November 24, 2003, created a joint venture between Western Utah Copper Company and Palladon Ventures (Palladon Ventures, 2003) and provided financing and mining expertise and still let Mark Dotson pursue his personal vision of retaining operational control.

According to the deal, Palladon Ventures was to explore the mineral area and arrange financing for development. However, this deal fell apart over the few years that followed. Both sides sued each other for breach of contract. The lawsuits were settled under the agreement that Mark Dotson could buy out Palladon for $\$ 10$ million if the funds were paid by January 4, 2007 (approximately six months later) or, if that did not happen, Palladon would buy out Mark Dotson for the same $\$ 10$ million (Palladon Ventures, 2006). Palladon did not believe that Mark Dotson could 
raise the money, and so it hoped to obtain full ownership of this valuable asset and develop the mine according to its schedule and priorities.

\section{Financing}

Mark Dotson contracted with a financing expert in Salt Lake City to help him raise the $\$ 10$ million. His objective was to retain complete control of the company and its operations. Through the financing expert's contacts, $\$ 10 \mathrm{M}$ in hard money short-term loans was raised. Hard money loans are short-term loans similar to bridge loans. They are secured by assets and have very high interest rates. They are almost never issued by banks or deposit institutions and, in this case, they were issued by private investors known by the financing expert. The $\$ 10$ million carried an interest rate of $24 \%$ with a due date of July 4, 2007 and a default penalty of $1.5 \%$ of the loan per day. The financing expert was already preparing long-term financing in order to repay the hard money loans by the July 4, 2007 due date and provide development funds.

\section{Long Term Financing}

The financing expert working with Mark Dotson arranged for a $\$ 100$ million loan from Credit Suisse. The bank required that the mill be built by a well-known contractor who would guarantee its operation and required a waterfall schedule for prepayment. This type of schedule is one that places restrictions on revenue to cover specific requirements by priority before management can do anything else with funds. Priorities, for example, started with a reserve to pay the loan interest, then taxes, then maintenance followed by other specific priorities (a sample waterfall schedule is included in Appendix C). Mark Dotson disagreed with these restrictions and exhibited the same distrust of the large corporations that the former claim-holding "old timers" had exhibited. He believed that he could build the mill for a fraction of what a well-known contractor would charge, and he refused the offer from Credit Suisse, calling them "thieves and liars" and claiming that they wanted control of his company. The financing expert considered the offer from Credit Suisse to be a very good opportunity and responded to Mark's ideas with shock. On January 4, 2007, construction on the mill began, even though long-term financing was not in place. Instead, the remaining amount of the hard money loan, and an additional $\$ 2.5$ million raised from the same private investors, was used to start the construction of the mill.

With the hard money loan coming due, Mark needed another source of long-term financing. The next source of funds considered by the financing expert was Still Water Capital, a real estate hedge fund on the east coast. They promised $\$ 55$ million by the July 4, 2007 date required to avoid the penalty on the hard money loan. On the day of the deadline, Still Water Capital reported having problems with its real estate funds and failed to meet the commitment; instead, it promised \$15 million by August. Unfortunately, in August when Still Water Capital was scheduled to provide the $\$ 15$ million, as one of the casualties of the housing bust and the U.S. financial crisis, it shut down operations and began a court-supervised restructuring (Headfund Alert, 2011).

The hard money loans, now due, were accruing a penalty of $1.5 \%$ of the loan principal per day. The mill was partially built and required more money for completion. While possible legal claims existed against Still Water Capital, there was no time to litigate and, even if litigation were pursued, it presented a high risk that there would be no assets to claim. Management shifted into emergency mode in an effort to save the business and pay back the original investors, many of whom were personal friends of management. Because U.S. real estate investment was now falling apart, and because commodity values were skyrocketing, the assets of Western Utah Copper Company continued to retain high value. As a result of this high value, the hard money lenders were willing to be "patiently impatient" and provided a window of opportunity for management to act.

In a further search for funding, management selected a 506 private equity offering. The Security and Exchange Commission (SEC) Rule 506 of regulation D allowed companies to sell private equity to sophisticated investors with few disclosures and limited financial statements (SEC, 2003). However, the securities could not be advertised and resold publicly. An additional $\$ 10$ million was raised through the private equity offering. However, this was not enough to finish the mill and start operations. 


\section{A Stock Promoter}

During the fall of 2007 when the 506 offering had come up short and the national credit crisis was becoming significant, Wilt Blum presented himself to Mark Dotson. He was a self-employed stock promoter who ran a Salt Lake City public relations firm (Oberbeck, 2009). He promised Western Utah Copper that he could raise $\$ 55$ million equity in three months with a reverse merger. He would create a company to merge with Western Utah Copper, and equity would then be sold in the new company. However, the financing expert warned against this approach, since he believed that new companies should achieve significant sales prior to an initial public offering. However, the current shareholders liked the idea; it provided the opportunity for public sales of their private shares.

In January 2008, Copper King Mining Company was formed and merged with Western Utah Copper Company. Equity was sold under SEC Rule 144, which provided an exemption for the public sale of unregistered private placement offerings if a number of conditions were met (SEC 2003). Wilt Blum found what he believed were the necessary conditions and started the public sale of stock using ticker symbol CPRKQ.PK. The value of a share on the pink sheets rose from $\$ 0.01$ to $\$ 0.57$ in the first week. However, a year later, the stock was back to $\$ 0.01$ and eventually fell further (Oberbeck, 2010 May). By the end of March, Walt Blum had not raised any significant money for the company but had profited from his personal trading of the Copper King Stock. The company officers continued to raise money through personal promotion of private placement offerings. Eventually, over $\$ 12$ million dollars were raised with the Rule 144 stock sales, from which Wilt Blum kept \$3.2 million (Oberbeck, 2009). These stock sales ended up attracting approximately 6,700 individual investors, with outstanding shares of over 5 billion.

By the summer of 2008, the holders of the hard money loans had lost whatever patience they had had and demanded repayment with interest and penalties. The financing expert again turned to Credit Suisse; the company sent in a renowned mining expert, who identified the project as financially viable as long as copper remained over $\$ 1.50$ per pound (copper was regularly selling for over $\$ 4.00$ per pound). With this news, Credit Suisse made another offer, the terms of which gave Credit Suisse some ownership, a place on the board, a role in management, and the same waterfall schedule as previously offered. Mark Dotson, now feeling more humble and flexible, verbally agreed to this offer with Credit Suisse. However, the formal contracts sent by Credit Suisse required that the hard money loans be moved to a second lien position behind Credit Suisse. The hard money lenders saw no benefit in giving up their first position rights, and thus the second opportunity with Credit Suisse was unsuccessful (Oberbeck, 2010).

\section{OPERATIONS BEGIN AND END RAPIDLY}

In March 2009, the processing mill opened (Romboy, 2011b). The local community of Milford, Utah, gathered and celebrated what they hoped would secure the economic future of the struggling town. Mark Dotson shook hands and received hugs from the ecstatic town residents. A video of a tour of the site taken shortly after this grand opening is available on youtube.com. Copper King Mining Mill Tour July 162009 (8:59)

Mark Dotson encouraged this enthusiasm, stating "we have virtually an ocean of copper out there. We believe we have enough resources to operate this endlessly." In addition, he promised \$103 million in annual revenue (Romboy, 2011 b, para. 2). At the time, no one (especially Mark) expected these words to come back and haunt him. However, the mill had a slow start. Each deposit of copper has unique attributes that required adjustments by experts in the milling process in order to perform extraction. Although the mill was well built and employed the latest technology, the early operations were disappointing. Tom Munson, a lead inspector with the Utah Division of Oil, Gas, and Mining said, "[Dotson] thought he had the process all figured out, but he never really did. He wouldn't let anyone tell him anything. I think that was their real downfall" (Romboy, 2011b, para. 2). Mark Dotson was tight-lipped about the operation and refused to share the milling results with the investors who had patiently waited for over two years past the due date of their loan. Very little copper was being sold, and expert consultants said that $\$ 5-7$ million more was needed to finish the startup and perfect the milling process.

In early 2010, after several weeks of no pay, the mill workers were sent home (Foy, 2010). Then, in May of that year, the hard money lenders announced that they were forcing involuntary Chapter 7 bankruptcy. The company preempted this move by filing voluntary Chapter 11 bankruptcy on May 15, 2010, almost three years after the hard money loans were originally due and after a total of over $\$ 50$ million had been raised (CKB, 2011). At this time, 
Mark Dotson was removed from the company. His dream of personally assembling, building, and running a copper empire seemed to be ruined.

\section{Bankruptcy and the SEC}

The bankruptcy proceedings were complicated and difficult. Over 70 gigs of documents and dispositions were provided to the court. The number of claimants was large, and many of them had individual deals. John Bryan, a well-known Los Angeles-based bankruptcy expert famous for advising Prince Andrew and his then-wife Sarah Ferguson, was brought in to navigate the company through the legal mazes. He then became CEO (Romboy, 2011a). The major parties in the bankruptcy were the hard money lenders, the equity owners, suppliers, and the holders of lease and mining rights who were due royalties (CKB, 2011). Each party had their own agenda. Various claimant groups were formed, some of which had created websites accusing other groups of perjury and fraud. The bankruptcy proceedings involved these kinds of acrimonious accusations along with thousands of filings, claimants, and changes in venues.

In June 2010, the SEC regulators further complicated the situation by filing suit against Mark Dotson and Wilt Blum over the sale of the unregistered securities (Oberbeck, 2011). They claimed that Blum had bought and sold far more shares than were authorized and that Mark Dotson had exaggerated the opportunity of the mine (Foy, 2010). Others accused Blum of personally benefiting from a pump-and-dump scheme in which the stock price was artificially pushed up through publicity (SEC, 2003). The New Copper King management fully cooperated with the SEC. The new CEO John Bryan said, "We cannot have any exaggeration of any data ever again" (Romboy, 2011b, para. 3). The undeveloped assets of Copper King were thought to be valuable enough to provide repayment of all loans, including some return to the equity holders.

However, in this bankruptcy, all parties had different motivations and skills in navigating the legal proceedings. Some parties tried to wipe out the lower claimants in order to obtain a more favorable settlement for themselves. The task of getting all parties to agree and compromise took incredible skill. Several parties wanted to force a quick shutdown and sale in order to gain sole ownership of the assets. Nevada Star was owed royalties and lease payments from the Hidden Treasure mine. Nevada Star filed suit for breach of contract, asking for a $\$ 60$ million settlement. This had the effect of scaring away potential Chinese investors who were waiting in the wings, thereby potentially forcing a quick sale of assets and wiping out the equity holders. Nevada Star would then likely own the assets of Copper King after paying off the senior debt holders. Some accused Nevada Star of illegally colluding with the senior debt holders.

One of the more recent lenders was Empire Bank of Columbus, Ohio. This lender was a specialist in bankruptcy and recognized the value of the Copper King assets. The judge allowed Empire Bank to make DIP loans (lender in possession loans) to keep the operation afloat while a settlement was negotiated (Henes, 2009). Because companies in bankruptcy have limited financing options, DIP loans can charge high rates and fees and receive court approval for security. DIP loans musts be repaid or settled before a company can emerge from Chapter 11.

John Bryan and his company used their bankruptcy expertise to negotiate a settlement with the warring parties, contingent upon an uncontested Section 363 settlement to avoid Chapter 7. Such a settlement allowed the assets to be sold clear of encumbrance in return for making an agreed-upon payment to the parties in the bankruptcy. This settlement forged a deal with Nevada Star, paid about $\$ 18$ million to the senior debt holders, and provided $1 \%$ equity in the new entity to existing shareholders. The stockholders were essentially cut out, as they received only $1 \%$ of the new entity. However, no one wanted to litigate, since the judge had already recognized that the senior debt was owed a value of $\$ 53$ million (CKB, 2011).

\section{CONCLUSION}

Mark Dotson traveled a long and troubled road. He assembled the claims, attracted interest from many investors, and eventually raised over 50 million dollars. However, in the end, he failed. He was removed from the company, and his assets were distributed to other parties. He tried at least five different approaches to fund the startup (joint venture, hard money loans, waterfall loan, private equity, and rule 144 public offering). Each of these approaches 
had specific benefits and constraints to management and investors. Originally, he was unwilling to accept investors' demands for some level of monitoring and control of operations. Investors, of course, required these terms in order to mitigate the risks they faced in both debt and equity contracts. Because of his experiences, Mark Dotson was left to wonder, given all the benefits and constraints of the various financing options, which of the financing approaches should he have used and which should he have avoided?

\section{INSTRUCTOR'S NOTES}

The Copper King case can be used in a number of finance classes such as: corporate finance, financial institution management, money and banking and entrepreneurship classes. It can be used as a review after discussing financial markets and institutions to highlight the role of asymmetric information and moral hazard and what tools are used to mitigate these market inefficiencies. In entrepreneurship classes it can be used to show the variety of financing options available and the associated benefits and challenges of each option. This case has been used successfully at both the undergraduate and graduate level.

\section{Discussion Questions}

1. Given the estimated EBITDA and investment needs what rate of return could this investment earn? Should Investors be interested?

2. Calculate the total due including interest and penalty on the $\$ 10$ million hard money loan as of March 2009 when the mill started up.

3. What are the constraints on management as well as the benefits of each of these financing alternatives? Are these restrictions reasonable?
a. Hard Money Loans
b. Credit Suisse Waterfall loan
c. Private Equity
d. Public Stock Sale

4. How did the loan restrictions protect the lenders against risk? Could the various parties have made different choices or compromised earlier to avoid bankruptcy and earn a return on this valuable asset?

5. Optional Question: Did the fact that the company tried to chart a course unique from the rest of the industry cause it to run into problems?

\section{EPILOGUE}

The bankrupt company was purchased by Empire Advisors of Columbus, Ohio and Clarity Partners of Los Angeles. The new operation is called CS Mining. A new experienced management team was brought in to run the company. The mine and mill now employ about 100 people and are now producing more than 1 million pounds of copper per month and generating positive EBITDA.

A federal judge has entered final judgment against Mark Dotson and Wilt Blum in the case brought by the SEC. Both are barred from participating in any penny stock offerings. Wilt Blum was required to return the $\$ 3.8$ million that he earned from the sale of Copper King stock.

\section{AUTHOR BIOGRAPHY}

Richard Parsons, Ph.D., from the University of Utah in Economics also has CMA and CIPM certifications. He was a senior financial executive with Mars, Incorporated where he was involved with many business and financial plans for twenty five years.

\section{REFERENCES}

CKB - Equity Share Holders Committee. (2011). Copper King bankruptcy web site. Retrieved on Aug 29, 2011 from: http://cprkbk.com.

Foy, P. (2010, May 21). Mining outfit in Utah shuts down, files bankruptcy. The Salt Lake Tribune. Retrieved on Aug. 29,2011 
from: http://archive.sltrib.com/article.php?id=9369015\&itype=storyID

Headfund Alert. (2011, Jan. 9). Stillwater hits snag in restructuring effort. Retrieved on Oct. 25, 2011 from: http://hfalert.com/headlines.

Henes, J. (2009, Aug. 12). DIP loan - the new "It" investment. CNBC Web Site. Retrieved on Aug.31, 2011 from: http://www.cnbc.com/id/32391841/henes.

Oberbeck, S. (2009, April 2). Copper King Mining opens mill in Bever County. The Salt Lake Tribune. Retrieved on Aug 29 , 2011 from: http://archive.sltrib.com/article.php?id=12058036\&itype=NGPSID.

Oberbeck, S. (2010, May 20). Utah's Copper King Mining files for chapter 11. The Salt Lake Tribune. Retrieved on Aug 29, 2011 from: http://archive.sltrib.com/article.php?id=9335062\&itype $=$ storyID.

Oberbeck, S. (2011, June 10). SEC sues Utah's Copper King Mining, others over share sales. The Salt Lake Tribune. Retrieved on Aug 29, 2011 from: http://archive.sltrib.com/article.php?id=15516205\&itype $=$ storyID.

Palladon Ventures. (2003). Press release Nov. 24, 2003. Retrieved on Oct. 25, 2011 from: www.Palladonventures.com.

Palladon Ventures. (2006). Press release Aug 28, 2003. Retrieved on Oct. 25, 2011 from: www.Palladonventures.com.

Romboy, E. (2011a, June 10). Utah copper mine deceived investors with fraudulent claims, SEC says. The Deseret News. Retrieved on Aug. 31, 2011 from: http://www.deseretnews.com/article/705374294/Utah-copper-mine-deceivedinvestors-with-fraudulent-claims-SEC-says.html?pg=al.

Romboy, E. (2011b, July 3). Risky venture: Copper mining in Milford brimming with high hopes, fears of failure. The Deseret News. Retrieved on Aug. 31, 2011 from: http://www.deseretnews.com/article/705375654/Risky-venture-Coppermining-in-Milford-brimming-with-high-hopes-fears-of-failure.html?pg=all.

SEC. (2003). Securities Act Rule 144: Pump and dump schemes, rule 506 of regulation D. Retrieved on Aug. 31 , 2011 from: http://www.sec.gov/answers/rule144.htm. 


\section{COPPER KING MINING COMPANY APPENDIX}

\section{Appendix A - Copper King Timeline}

1989- 2003

Nov. 2003

Aug. 2006

Nov.- Dec. 2006

Jan. 4, 2007

Jan.-Feb. 2007

Jan. 2007

March 2007

July 4, 2007

Aug. 2007

Aug.-Dec. 2007

Fall 2007

Jan. 2008

March 2008

April 2008

July 2008

March 2009

June 2009

June-Dec. 2010

May 15, 2010

May 18, 2010

June 10, 2010
Dotson assembles claims

Dotson and Palladon sign a joint development deal

Dotson and Palladon sue each other for default and renegotiate their deal

Dotson secures $\$ 10 \mathrm{M}$ in hard money loans

Dotson buys full interest from Palladon.

Long-term financing arranged from Credit Suisse for 100M Dotson turns down Credit Suisse

Mill construction begins

Long-term financing is arranged from Still Water Capital a real estate hedge fund. $\$ 55 \mathrm{M}$ to close on July 4.

Hard money loan due and $1.5 \%$ daily penalty begins. Still water capital reneges on commitment.

Still Water Capital shuts down in the middle of the real estate collapse.

Equity is raised through private 506 offerings of stock $=\$ 10 \mathrm{M}$

Wilt Blum presents himself to Western Utah Copper Company

Reverse merger between Western Utah Copper Company into Copper King, a Nevada Corp., takes place

Very little additional equity is raised. Financing is requested from Credit Suisse. An agreement is reached in personal conversations.

Follow-up paperwork requires the current first position debt move to second position and Credit Suisse assumes first position.

First position debt neglects to agree to this, and Credit Suisse does not compromise.

Media event - grand opening of mill

Production from mill starts

Mill underperforms

Lenders announce filing for involuntary bankruptcy Chapter 7

Company files voluntary bankruptcy Chapter 11 and brings in bankruptcy specialist to help company recover. Nevada Star files lawsuit trying to shut down Copper King and reclaim hidden treasure mine property. Chinese investors are scared away by Nevada Star.

SEC files suit against Mark Dotson, Wilt Blum 
Appendix B- Approximate Funds Raised

$\begin{array}{ll}\text { Initial Hard money } & \$ 10 \mathrm{M} \\ \text { Additional Hard Money } & \$ 3 \mathrm{M} \\ \text { Mortgage and secured Loans } & \$ 10 \mathrm{M} \\ \text { Unsecured debt } & \$ 10 \mathrm{M} \\ \text { Private Equity WUCC } & \$ 10 \mathrm{M} \\ \text { Private Equity CKKP } & \$ 12 \mathrm{M}\end{array}$




\section{Appendix C - Sample Waterfall Schedule Loan}

Security - A first-priority interest in

1. All accounts of the borrower.

2. All shares held of the borrower.

3. All rights, title, and interest of the Borrower in the mineral deposits and processing facilities.

4. All revenue accounts and accounts receivable.

5. Proceeds of any of the foregoing.

The project will establish and maintain accounts into which all proceeds from the sale of the products will be deposited. In addition, the project will establish and maintain customary secured accounts, including:

a. The construction proceeds account, into which all loan proceeds are deposited.

b. Revenue account into which all proceeds are deposited.

c. Debt service accrual (reserve monthly for quarterly payments).

d. Tax reserve account.

e. Major maintenance reserve account.

f. Mandatory capital expenditure account per engineers schedule.

g. Interest payment account, holding 6 months of scheduled interest payments.

h. Working capital reserve account.

i. Hedge reserve account (for hedges against metal futures).

Amounts in the hedge, working capital, and major maintenance and capital reserve account will be available to service the debt in the event of a shortfall.

Requirements of loan include an independent engineer's construction estimate of the mill and a $\$ 3,000,000$ upfront fee and warrants to the lender worth a percentage of ownership of the company. 